\title{
THE RELATIONSHIP BETWEEN THE PRELIMINARY RULING AND A FAIR TRIAL - ECHR PROSPECTIVE
}

The European human rights architecture is considered one of the most relevant regional human rights systems. In this context, the Council of Europe and the European Union play crucial roles. All the EU member states happen to be members of the Council and Europe as well as Contracting Parties to its most remarkable treaty, the European Convention on Human Rights (hereinafter: ECHR). This paper attempts to examine an issue arising from the two most significant tools of the two regimes, on the EU side that would be the preliminary ruling procedure and on the ECHR side, the right to a fair trial. The analyzed issue is whether the refusal by the national court to submit a preliminary ruling request as initiated by the party in national proceedings can lead to violation of Article 6 of the ECHR. As concluded in the paper and supported by the relevant case law, a party's submission before a domestic court that is a member of the EU and a Contracting Party to ECHR, might embody the violation of Article 6 if the court of last instance rejects the reference of parties to initiate a preliminary ruling procedure without giving reasons for it. However, similarly to the relationship between the EU legal order and ECHR, the analysed issue also has many open concerns.

Keywords: preliminary ruling, fair trial, Article 6, case law, European human rights architecture

\section{INTRODUCTION}

In the European human rights architecture, the Council of Europe and the European Union are certainly some of the most relevant, if not the most relevant, players. All the EU member states happen to be members of the Council and Europe and Contracting Parties to its most significant treaty, the European Convention on Human Rights (hereinafter: ECHR). This paper attempts to examine an issue arising from the two most significant institutes of the two regimes, on the EU side that would be the preliminary ruling procedure and on the ECHR side, the right to a fair trial. What happens when these two institutions

* Doctoral candidate, Doctoral School Faculty of Law, University of Pécs, Email: marijadaka@gmail.com 
are cross-checked? The issue arising is whether refusing a motion to submit preliminary ruling references by the national court can be regarded as a violation of the right to a fair trial as per ECHR case law. Such a violation of Article 6 has already occurred on several occasions, although it cannot be stated that the court has a well-established case law on the subject matter. The stance supported in this paper is that the European Court of Human Rights (hereinafter: the Court, ECtHR) can rather be considered only a promoter of minimum standards.

The paper first outlines the importance of Article 6, then elaborates upon the case law involving the EU before the ECtHR and lastly contextualizes the case law on Article 6 in the case of refusal to initiate a preliminary ruling procedure.

However, analyzing the tendencies, it needs to be pointed out that the ECtHR is more frequently involved in the analysis of the EU courts' matters than it was the case some decades ago. As reiterated by Advocate General Wahl, "Nowadays, (...) the European Court of Human Rights [is] regularly seised of proceedings relating to an alleged failure to refer under Article 267(3) TFEU. ${ }^{223 "}$

\section{ARTICLE 6 ECHR IN A NUTSHELL}

The overall significance of Article 6 can be proven in both quantitative and qualitative terms.

The applications analyzed by the ECtHR predominantly refer to the alleged violation of Article 6. In 2019, from the judgments delivered by the Court, nearly a quarter of the violations concerned Article $6 .{ }^{224}$ When elaborating on Article 6, as stated by some authors, (Doobay, 2013p.261) while many claimants raise detailed allegations about specific provisions of Article 6, the Court tends to take a more holistic view and to consider the overall fairness of the proceedings taking into account the interests of other parties to the process." 225

As for the qualitative terms, Article 6 is also quite central to the enforcement of other fundamental rights. The 'rule of law', which is set out in the Preamble to the ECHR and which is central to its vision, cannot exist if there is no fair trial. ${ }^{226}$

In general, it can be concluded that relating to Article 6, the Court has a well-established case law, although Article 6 also entails issues which have not received enough attention so far. Such an example is whether the refusal of a motion set forth by a party before a national court to initiate a preliminary ruling procedure can be considered breaching Article 6 . Whenever referring to a refusal within this paper, it will always mean the issue

223 OPINION OF ADVOCATE GENERAL WAHL delivered on 13 May 2015 Joined Cases C72/14 and C197/14 ECLI:EU:C:2015:319.

${ }^{224}$ Convention for the Protection of Human Rights and Fundamental Freedoms CETS No. 05. https://www. coe.int/en/web/conventions/full-list/-/conventions/treaty/005 (09.09.2020).

${ }^{225}$ Doobay, A. 2013The right to a fair trial in light of the recent ECtHR and CJEU case-lawERA Forum 14, p. 251-262.

${ }^{226}$ Schabas,W.A. 2015 The European Convention on Human RightsA Commentary Oxford: Oxford University Press. 
as described above. Needless to say, Article 6 does not expressly cover the preliminary ruling procedure, a well-known milestone from the EU legal order, however gradually the ECtHR recognized it within its evolutive case law.

The aim of this paper is to analyze the criteria established by ECtHR when assessing whether the refusal by the national court to refer for a preliminary ruling as initiated by the party can amount to violation of Article 6 . However, when analyzing this rather complex issue, it is important to underline that the same issue can be brought up as an alleged violation of Article 13 - the right to an effective remedy, ${ }^{227}$ which could represent another dimension of analysis not pursued in this paper.

Besides the variety of articles that may entail the alleged issue, it is important to have in mind the variety of angles from which the issue can be scrutinized. Namely, the question of refusal to initiate a preliminary ruling procedure in the light of a potential violation of the right to a fair trial can also be analyzed from constitutional aspects. This relates to the national players within the European human rights architecture, most commonly national constitutional courts, and it mainly concerns the question of what criteria are applied by the EU member states and constitutional courts in order to assess what the consequences in relation to the potential violation of the right to a fair trial are in cases where the motion to initiate a preliminary ruling procedure is refused by the competent courts. ${ }^{228}$ In that regard, it would be interesting to examine whether the consequences differ in such cases in the procedural laws of the EU member states and before the ECtHR.

However, when establishing the context to analyze the interferences between the right to a fair trial and refusing the initiative to refer to a preliminary ruling, it of course cannot be examined in isolation, bearing in mind the practice and features of the ECtHR's modus operandi. As outlined in case Otto Preminger, the Convention is to be read as a whole, in harmony with the logic of the Convention ${ }^{229}$

Although the refusal by the national court to initiate a preliminary ruling procedure can amount to violation of Article 6, the exact reasons for establishing a violation and the extent of the given reasons are still fluid.

\section{SOME REFLECTIONS ON THE RESPONSIBILITY OF EU MEMBER STATES FOR VIOLATIONS OF ECHR WHEN EXECUTING EU LAW}

A comprehensive overview of the relationship between European Union and European Court of Human Rights is quite a far-reaching issue. In this chapter, I will only outline the

\footnotetext{
227 See e.g.: Adams and Benn v. United Kingdom, Application No.: 28979/95,30343/96 ECLI:CE:ECHR:1997:0113DEC002897995, although it is important to outline, that the ECtHR emphasized in the case of Ullens de Schooten and Rezabek v. Belgium Application No.: 3989/07 and 38353/07 that Article 6 offers a higher level of protection, including thus the protection safeguarded by Article 13 .

${ }^{228}$ In the Hungarian context, the right to a fair trial is enshrined in Fundamental Law Article XXVII. For a European comparative note see Valutyte, R. 2012. Legal consequences for the infringement of the obligation to make a reference for a preliminary ruling under constitutional law. Jurisprudencija: mokslodarbai.

${ }^{229}$ Otto Preminger Institut v. Austria, Application No.:13470/87ECLI:CE:ECHR:1994:0920JUD001347087 para 47.andKlass and Others V. Germany Application No.:5029/71 ECLI:CE:ECHR:1978:0906JUD000502971 para 68.
} 
main areas of interference. In a formal sense, both the Charter of Fundamental Rights and the ECHR contain provisions referring to the other ${ }^{230}$, however the informal relationship should not be underestimated either.

Currently the relationship between the EU and the ECHR is to the greatest extent guided by a failed attempt of the EU to join the ECHR. As long as this process is on hold, we can only rely on case-law and more precisely, the Bosphorus presumption, according to which state actions taken in compliance with the obligations arising from the EU are justified as long as the EU is considered to be protecting fundamental rights, as regards both the substantive guarantees offered and the mechanisms controlling their observance in a manner which can be considered at least equivalent to that for which the Convention provides. ${ }^{231}$ The Bosphorus presumption has been further nuanced in the case of Avotinš in which the Court concluded that although the Bosphorus presumption was to be applied, it showed a cautious approach with regard to an automatic and mechanical application of the principle of mutual recognition..$^{232}$

\section{INTERFERENCE BETWEEN ARTICLE 6 AND THE PRELIMINARY RULING PROCEDURE}

\subsection{Access to a court as read in ECtHR case law}

Article 6 does not explicitly include access to a court; this right emerged from a creative interpretation of the provision by the Court in the leading case of Golder v. the United Kingdom. ${ }^{233}$ As elaborated by the ECtHR in Roche, the right of access to a court is an inherent aspect of the safeguards enshrined in Article 6, referring to the principles of the rule of law and the avoidance of arbitrary power, which underlay much of the Convention. ${ }^{234}$

According to the Golder case, Article 6 secures to everyone the right to have any claim relating to his civil rights and obligations brought before a court or tribunal. ${ }^{235}$ The rule of law and the avoidance of arbitrary power are crucial principles underlying the Convention ${ }^{236}$

When it comes to access to a court in the EU law terms, the Court reiterated in the Herma case that the Convention does not guarantee, as such, any right to have a case referred to the ECJ for a preliminary ruling, Nevertheless, refusal of a request for such a referral may infringe the fairness of proceedings if it appears to be arbitrary ${ }^{237}$

\footnotetext{
${ }^{230}$ However, the ECHR contains in Article 59 (2) only a reference on the accession of the EU to the ECHR.

${ }^{231}$ Bosphorus Hava Yolları Turizmve Ticaret Anonim Şirketi v. İreland, Application No.: 45036/98 ECLI:CE:E CHR:2005:0630JUD004503698para 55.

${ }^{232}$ Avotins v. Latvia, Application No.: 17502/07ECLI:CE:ECHR:2016:0523JUD001750207para 116.

${ }^{233}$ Schabas W.A. Ibid. and Golderv. United Kingdom, Application No.: 4451/70ECLI:CE:ECHR:1975:0221JUD000445170 para. 28.

${ }^{234}$ Roche v. United Kingdom, Application no. 32555/96 ECLI:CE:ECHR:2005:1019JUD003255596para. 116.

${ }^{235}$ Golderv. United Kingdom, ibid.para 36.

${ }^{236}$ Taxquet v. Belgium, application no. 926/05, ECLI:CE:ECHR:2010:1116JUD000092605para. 90 and Baydarv. The Netherlands, application no. 55385/14ECLI:CE:ECHR:2018:0424JUD005538514para. 39.

${ }^{237}$ Herma v. Germany, Application No.: 54193/07ECLI:CE:ECHR:2009:1208DEC005419307, para. 2.
} 
From this question derives the issue analyzed in this paper, namely what are the consequences of refusing to initiate a preliminary ruling procedure upon the motion of a party. Needless to say, this issue arises only if the state in question is a member state of the EU and the Contracting Party to ECHR. Such a situation occurs if the national court against whose decision there is no remedy ignores or rejects the motion of a party or parties to initiate a preliminary ruling procedure and does not give reasons for such refusal.

However, in ECHR practice, Article 6 -unlike some other Articles- is not labeled as an absolute right ${ }^{238}$, therefore the right to compel a court to refer a case for a preliminary ruling cannot be described as absolute either: as outlined in this chapter it is rather the consequence of ECHR acquis.

\subsection{EU perspective - the preliminary ruling procedure and the Charter of Fundamental Rights}

The preliminary ruling procedure is one of the cornerstones of the EU the legal order. One would assume that it also means that all the aspects of the preliminary ruling procedure are therefore regulated in a crystal-clear way.

As stated by some authors (Broberg \& Fenger, 2011 p. 276) the prominent role of the preliminary reference procedure in the EU legal system, together with a very considerable number of preliminary ruling cases, some of them e.g. Dorobantu ${ }^{239}$, contain specific fundamental rights interpretations. These have been decided by a court, which naturally leads us to assume that all more important aspects of the preliminary ruling procedure have long been clarified. ${ }^{240}$ However, this is not the case. On a positive note, when it comes to the Charter of Fundamental Rights, a clear increase in requests for a preliminary ruling mentioning the Charter can be observed ${ }^{241}$.

As per Article 267 of the TFEU ${ }^{242}$, the aim of the preliminary ruling procedure is two-fold: to interpret the Treaties; and to interpret and decide on the validity of secondary norms. Therefore, it could be concluded that those aims also have harmonizing effects in a sense.

The national courts have the right to initiate preliminary proceedings, although in some cases it is a duty not merely a right ${ }^{243}$. As stated by some authors (Gerards 2014, p. 642), the existence of an obligation rather than a mere competence, to refer preliminary questions

\footnotetext{
${ }^{238}$ More on absolute rights in ECHR, see e.g. Mavronicola, N. 2012. What is an "absolute right"? Deciphering Absoluteness in the Context of Article 3 of the European Convention on Human Rights Human Rights Law Review, 12(4), p. 723-758.

${ }^{239}$ Dumitru Tudor Dorobantu. Case C-128/18. ECLI:EU:C:2019:857See the critical appraisal: Mohay Á. 2020 The Dorobantu case and the applicability of the ECHR in the EU legal order Pécs Journal of International and European Law.

240 Broberg, M \&Fenger, N 2011, Preliminary references as a right: But a right for whom? The Extent to which Preliminary Reference Decisions can be Subject to Appeal, European Law Review, vol. 36, no. 2, pp. 276-288.

${ }^{241}$ Fundamental Rights Report 2019, Fundamental Rights Agency, ISBN 978-92-9474-895-9.

${ }^{242}$ Consolidated version of the Treaty on the Functioning of the European Union OJ C 326.

${ }^{243}$ BlutmanL. 2014 Az Európai Uniójoga a gyakorlatban Budapest, HVG ORAC p.122.
} 
to the CJEU in cases where new issues of interpretation have arisen, has resulted in a frequent involvement of the CJEU in national cases and a major impact of its judgments and interpretations. ${ }^{244}$

Such a case might occur if there is no remedy against the decision of a national court. The exceptions to the duty to refer for a preliminary ruling were recorded by the Court of Justice of the European Union (hereinafter: CJEU) in the CILFIT case ${ }^{245}$ such as the cases of acteclair, acteeclairé and in the case in question are not relevant.

Referring to the Charter of Fundamental Rights, Article 47 (2) safeguards the right to an effective remedy and to a fair trial ${ }^{246}$ containing thus more specific provisions than Article 6 ECHR. Ironically, the possibility of private individuals to directly refer to the $\mathrm{CJEU}$ is rather limited which is in contradiction to its effectiveness ${ }^{247}$

Comparing Article 47 of the Charter and Article 6 of ECHR, they partially entail the same provisions, however - the Charter's personal, material and application scope is different. Also, the two fundamental rights documents have a converging minimum standard embodied in Article 52 (3) of the Charter. The Article governs the meaning and scope of the ECHR/Charter corresponding rights. In my view, this also means that the violation of Article 6, as per the papers analyzed issue, at the same time constitutes the violation of Article 47 of the Charter, if the circumstances of the case allow this (i.e. the case concerns the application of EU law in the sense of Article 51(1) of the Charter).

\subsection{Duty to refer in the light of Article 6 case law}

The ECtHR, and previously the Commission, have dealt with the issue for more than two decades. Initially ECtHR connected the issue pertaining to the refusal to initiate a preliminary ruling to the concept of arbitrariness. However, as seen from the procedural background, the Court did not succeed to set up a well-established case law despite the twenty-year time frame. The most recent judgment was delivered in February 2020 in the case of Sanofi Pasteur.

The court reached some rudimentary conclusions in the cases of Dotta ${ }^{248}$, Moosbrugger ${ }^{249}$ and Coëme. ${ }^{250}$ In the case of Moosbrugger, the applicant alleged the violation of Article 6 because the Austrian Supreme Court failed to refer a preliminary ruling to CJEU. In the case of Coëme, however, the violation was alleged to happen in a purely national context

\footnotetext{
${ }^{244}$ Gerards J. 2014 Advisory Opinions, Preliminary Rulings and the New Protocol No. 16 to the European Convention of Human Rights: A Comparative and Critical Appraisal Maastricht Journal of European and Comparative law p. 642.

${ }^{245}$ C-283/81 - CILFIT v Ministerodella Sanità.

${ }^{246}$ Charter of Fundamental Rights of the European Union2012/C 326/02.

${ }^{247}$ Galera Rodrigo S. 2015 The right to a fair trial in the European Union: lights and shadows Revista Investigacoes Constitucionais vol.2 no.2.

${ }^{248}$ Dotta v. Italy, Application No.: 38399/97, ECLI:CE:ECHR:1999:0907DEC003839997.

249 Peter Moosbrugger v. Austria, Application No. 44861/98, ECLI:CE:ECHR:1990:0305DEC001198186.

${ }^{250}$ Coëme and Others v. Belgium, Application No.:32492/96, 32547/96, 32548/96, 33209/96, 33210/96 ECLI:CE:ECHR:2000:0622JUD003249296.
} 
that is when the Belgian Court of Cassation rejected the motion to initiate proceedings towards Administrative Jurisdiction and Procedure Court. Despite the national context, because of the analogy, the Coëme case was referred on several occasions in the later case law.

So, in Moosbrugger, as in Coëme, the Court applied a restrictive interpretation and noted that Article 6 - and the Convention itself- does not guarantee, as such, any right to have a case referred by a domestic court to another national or international authority for a preliminary ruling. ${ }^{251}$ In Moosbrugger it specifically referred to the $\mathrm{CJEU}^{252}$ while in the Coëme case the dispute was about a national authority. Coëme also outlined that "the right to a court", of which the right of access is one aspect, is not absolute. ${ }^{253}$ Speaking of not being an absolute right, it is important to briefly refer to the margin of appreciation of ECHR Contracting States. The Court has extended the margin of appreciation to procedural guarantees also to Article 6 (1). ${ }^{254}$ According to the Court -inter alia in the Coëmecase- it is primarily on the national authorities, notably on courts, to resolve problems of interpretation of domestic legislation ${ }^{255}$. This was later repeated in the Bosphorus case as well. However, in that case the Court went even further by referring to the supranational layer of European human rights architecture, which is the Community, whose judicial organs are in a better position to interpret and apply Community law. ${ }^{256}$ This tells us how the ECtHR is aware of its mandate and role in guaranteeing human rights.

These initial conclusions were later on further expanded in the cases of Ullens de Schooten and Rezabek v. Belgium.

According to the first conclusion, an obligation is imposed onto domestic courts to give reasons for any decisions in which they refuse to refer a preliminary question, especially where the applicable law allows for such a refusal only on an exceptional basis. ${ }^{257}$

When it comes to the actual extent of the duty to give reasons, the Court analysed the CILFIT-exemptions ${ }^{258}$ and adopted its stance accordingly, reiterating that it was on the national courts against whose decisions there is no judicial remedy under national law, to decide "whether a decision on a question of Community law is necessary to enable them to pass judgment". The CILFIT judgment states that the exemptions to refer for a preliminary ruling are the following: if the national courts establish that the question "is irrelevant", that he Community provision in question has already been interpreted or that the correct application of Community law is so obvious as to leave no scope for any reasonable doubt" 259 . Therefore, when assessing whether for the national court there is no

\footnotetext{
${ }^{251}$ Coëme and Others v. Belgium, para. 114.

252 Moosbrugger v. Austria, para. 2.

${ }^{253}$ Coëme and Others v. Belgium, para. 114.

${ }^{254}$ See e.g.: Spielmann D. Allowing the Right Margin: The European Court of Human Rights and The National Margin of Appreciation Doctrine: Waiver or Subsidiarity of European Review? Cambridge Yearbook of European Legal Studies 14, p.381-418.

${ }^{255}$ Coëme and Others v. Belgium, para. 115.

${ }^{256}$ Bosphorus Hava Yolları Turizmve Ticaret Anonim Şirketiv. Ireland, para, 143.

${ }^{257}$ Ullens de Schootenand Rezabek v. Belgiumpara. 60.

${ }^{258}$ C-283/81 - CILFIT v Ministero della Sanità.

${ }^{259}$ Ullens de Schootenand Rezabek v. Belgium, para .56.
} 
need to refer for a preliminary ruling, the court has to give reasons for such conclusion based on the CILFIT criteria ${ }^{260}$.

Sticking to the concept of arbitrariness, the Court also further elaborated on the concept of arbitrariness, outlining that it is to say where there has been a refusal even though the applicable rules allow no exception to the principle of preliminary reference or no alternative thereto, where the refusal is based on reasons other than those provided for by the rules, and where the refusal has not been duly reasoned in accordance with those rules ${ }^{261}$.

Furthermore, when it comes to the national court, the Court did not rule out the possibility that where a preliminary reference mechanism exists, a refusal by a domestic court to grant a request for such a referral, in certain circumstances may infringe the fairness of proceedings - even if that court is not ruling in the last instance ${ }^{262}$. I personally consider such a scenario hard to imagine, since in that case, if the court is not of last instance, I consider it highly likely that ECtHR would not even examine the application as not all domestic legal remedies have been exhausted, which is a precondition enshrined as an admissibility criteria in Article 35 ECHR. ${ }^{263}$

Evaluating the conclusions from the Ullens case, according to some authors, the case set up qualitative but not quantitative criteria ${ }^{264}$.

Of further relevance is the Dhahbi case, which concerns, inter alia, the violation of Article 6. According to the factual background of the case, the Tunisian national applicant lodged an application with the national court seeking payment of a family allowance based on an agreement between the European Union and Tunisia. The applicant requested that a question be referred to CJEU for a preliminary ruling however, the Italian courts rejected, or possibly ignored, his request. Therefore, it is not clear whether the issue, which was disputed by the applicant, fell within the CILFIT-exemptions categories of acteéclairé, acteclaire or was considered not a relevant question. Furthermore, the decision of the national court did not even contain a reference to CJEU practice ${ }^{265}$. The Court reiterated the duty to give reasons, as already seen in the Ullens case, though without expressly referring to the case.

The violation of Article 6 was quite evident in the latter case. Therefore, it was not really challenging to the Court to establish a violation of Article 6. I personally consider that the judgment needs some more of a context and methodological guidance on the importance of the duty to give reasons, and for the sake of coherence, a referral to the Ullens judgment.

In the case of Baydar v. the Netherlands, the Supreme Court refused to refer the request of the applicant for a preliminary ruling to the CJEU. However, the Court did not find it a violation of Article 6. When assessing the non-violation, the Court acknowledged an additional aspect, i.e. the acceptance of using a summary reasoning in an accelerated

\footnotetext{
${ }^{260}$ Ibid., para 62.

261 Ibid., para. 59.

262 Ibid., para. 59.

${ }^{263}$ European Convention on Human Rights, op.cit.

${ }^{264}$ Majić H. \& Mintas Hodak Lj. 2019 Preliminary reference procedure and the scope of judicial review of the European Court of Human Rights EU and Member States - Legal and Economic issues.

${ }^{265}$ Dhahbiv. Italy , Application No.: 17120/09 ECLI:CE:ECHR:2014:0408JUD001712009 para.33.
} 
procedure as an acceptable practice ${ }^{266}$. The judgment refers to both the Ullens and the Dhahbi cases ${ }^{267}$.

By ruling on summary proceedings, I believe the ECtHR also ruled on the minimum standards of the duty to give reasons. Analysing the de minimis rule, the Court considered it acceptable to dismiss a complaint by mere reference to the relevant legal provisions governing such complaints if the matter raises no fundamentally important legal issue, referring to the John case ${ }^{268}$.

This case also had potential relevance from the point of view of the relationship between the ECHR and the EU legal order, because the European Commission was invited to intervene as a third party. However, the Commission informed the ECtHR that it did not intend to submit written observations, which was an unfortunate development, at least from the perspective of analyzing the EU-ECHR relationship.

As for domestic courts needing to provide reasons for their judgments and decisions, the ECtHR further pointed out that the extent to which the duty to provide reasons may vary according to the nature of the decision ${ }^{269}$, therefore it always has to be analyzed in concreto.

Another case in which the summary reasoning was sufficient is the Stichting Mothers of Srebrenica case. As concluded by the Court, having already found that the United Nations enjoyed immunity from domestic jurisdiction under international law, the Supreme Court was entitled to consider a request to the CJEU for a preliminary ruling redundant. ${ }^{270}$

In the case of Somorjai v. Hungary, the court stuck to its previously developed case-law. According to the factual description, the pension rights of the applicant under EU law were not taken into consideration by the domestic authorities. On the issue of the need for a preliminary ruling, the ECtHR noted that, as per the CJEU's relevant case-law, even if the initiative of a party is not necessary for a domestic court against whose decisions there is no judicial remedy under national law to be obliged to bring a question concerning the interpretation or the validity of EU law before the CJEU, it is solely on that court to decide in the light of the particular circumstances of the case ${ }^{271}$.

Besides the role of the domestic court, the ECtHR also ruled on its own role, reiterating its duty to ensure the observance of the obligations undertaken by the Contracting Parties to the Convention. This also means that the ECtHR is not competent to rule formally on the compliance with the domestic law, other international treaties or EU law. The task of interpreting and applying the provisions of EU law falls firstly to the CJEU, in the context of a request for a preliminary ruling, and secondly to the domestic courts in their capacity as courts of the Union. It is therefore primarily on the national authorities, notably the

\footnotetext{
${ }^{266}$ Baydar v. the Netherlands, Application No.:55385/14 ECLI:CE:ECHR:2018:0424JUD005538514, para. 50.

267 Ibid., para. 44.

${ }^{268}$ Ibid., para. 46.

${ }^{269}$ Ibid., para. 40.

270 Stichting Mothers of Srebrenica and others v. the Netherlands, Application No.:65542/12ECLI:CE:ECHR:2013:0611DEC006554212 para. 173.

${ }^{271}$ Somorjai v. Hungary, para. 61.
} 
courts, to interpret and apply the domestic law, if necessary, in conformity with EU law, the Court's role being confined to ascertaining whether the effects of such adjudication are compatible with the Convention ${ }^{272}$

In the case of Harisch v. Germany ${ }^{273}$ and Repcevirág Szövetkezet v. Hungary ${ }^{274}$ the Court confirmed its previous case law, pertaining to the criteria to assess the refusal to initiate a preliminary ruling procedure.

The most recent case in the subject matter is the Sanofi Pasteur v. France ${ }^{275}$ where the Court found violation of Article 6 based on the previously established criteria.

\subsection{The scale of duty to give reasons}

Bearing in mind that Article 6 is not an absolute right, the obligation of a domestic court does not guarantee, as such, any right to have a case referred by a domestic court to another national or international authority ${ }^{276}$. The role of the court is only to ascertain the reasons for the eventual refusal to initiate a preliminary ruling procedure in the light of Article 6. Therefore, in my understanding, the ECtHR can be characterized as a standard setter of minimal requirements. ${ }^{277}$

Analyzing the exact volume of the duty to give reasons based on the case law, the cases can be classified in the following way:

1) The decision contains no reasons due to ignorance of domestic courts.

2) The decision is reasoned, based on CILFIT or any other criteria.

3) The decision does not have to be reasoned.

Referring to the first scenario, as seen in the Dhahbi case, the fact that the domestic court ignores to justify the decision can be relevant in ECHR contact and might lead to the violation of Article 6. As already outlined in this particular case, the applicant's motion was sufficiently elaborated while the domestic court ignored to give reasons, therefore in such cases the violation of Article 6 is highly probable.

Referring to the second scenario, if the national court justifies the decision, the justification as a certain qualitative standard has to be aligned with the criteria stemming from either Ullens-case or any other criteria, such as elaborated in Baydar and Stichting Mothers of Srebrenica cases.

The third scenario relates to the issue where the decision does not have to be justified. Such case occurred in the John case where submissions of the applicant neither contained

\footnotetext{
272 Somorjai v. Hungary, para. 53.

${ }^{273}$ Harisch v. Germany, Application No.:50053/16 ECLI:CE:ECHR:2019:0411JUD005005316

${ }^{274}$ Repcevirág Szövetkezet v. Hungary, Application No.:70750/14 ECLI:CE:ECHR:2019:0430JUD007075014

${ }^{275}$ Sanofi Pasteur v. France, Application No.: 25137/16ECLI:CE:ECHR:2020:0213JUD002513716

276 Somorjai v. Hungary, para 54.

${ }^{277}$ Limante A. Refusal to refer for preliminary ruling and a right to a fair trial: Strasbourg court's position KSLR EU Law Blog available at: https://blogs.kcl.ac.uk/kslreuropeanlawblog/?p=1098\#.XtdeqmgzaUk.
} 
an express request for a reference under Article 234 EC Treaty nor the precise reasons for the alleged necessity of a preliminary ruling. ${ }^{278}$

Even from these scenarios, it is easy to see that the acquis developed by ECtHR is rather fragile and established on in concreto basis. However, there is a high probability that the domestic court of last instance has a duty to give reasons in case of rejecting the submission of parties to initiate preliminary ruling procedure. Although the scale to give reasons is diverse, referral to CILFIT-exceptions is usually considered dominant. However, it cannot be asserted with certainty from the case law to what extent this should be detailed. On the other hand, what is probable is that if the domestic court fails to provide reasons, this might be considered arbitrary and therefore in breach of Article 6 .

\section{CONCLUDING REMARKS}

The party's submission before a domestic court of a state which is a member of the EU and a Contracting Party to ECHR at the same time might lead to the violation of Article 6 if the court of last instance rejects the submission of the parties to initiate a preliminary ruling procedure and does not give reasons for it. According to the ECtHR's view, there is an autonomous, yet not absolute, right to a preliminary ruling from the CJEU that might be infringed due to the unreasoned refusal to submit the applicant's request to the CJEU. ${ }^{279}$

However, such scenario occurs only in ultima ratio cases, because the ECtHR has held on numerous occasions that it is primarily up to the national courts to interpret and apply the domestic law, if applicable in conformity with EU law, and to decide whether it is necessary to seek a preliminary ruling ${ }^{280}$. This also applies in cases when that law refers to international law. Equally, the EU's judicial institutions are a better place to interpret and apply EU law. ${ }^{281}$

In my view, with the existing duty to give reasons as imposed by the ECtHR, the ECtHR contributes to the dialogue between the national courts and the CJEU itself. While, if we take into consideration Protocol No.16, the dialogue occurs between the designated national courts and the ECtHR, the Strasbourg and Luxembourg courts maintain a different kind of dialogue with the national courts, yet still there is some convergence between the effects of their decisions and judgments, as in the case of the CILFIT exceptions.

The ECtHR only assures, as inter alia in the Somorjai case, the court's role being confined to ascertaining whether the effects of domestic adjudication are compatible with the Convention. This is in line with the role of the ECHR as read per Article 53 of the Convention. The underlying importance of the ECHR, within the European human rights architecture lies in the fact that this minimum standard sometimes also entails the maximum level protection.

\footnotetext{
${ }^{278}$ Lutz John v. Germany Application No.: 15073/03ECLI:CE:ECHR:2007:0213DEC001507303, para 2.

${ }^{279}$ Lacchi, C.2015. The ECtHR's Interference in the Dialogue between National Courts and the Court of Justice of the EU: Implications for the Preliminary Reference Procedure Review of European Administrative Law, 8(2), p. 95-125.

${ }^{280}$ See e.g. Harisch v Germany, para. 33.

${ }^{281}$ See Bosphorus case, para. 143.
} 
From the Bosphorus case onwards, we have witnessed the possibility that the ECtHR reviews in an indirect manner the ECHR compatibility with the EU legal order, or in other words, it will not refrain itself from interfering with the cases which fall under the exclusive EU jurisdiction. According to some authors, in Bosphorus the ECtHR retained the role of the ultimate guardian of the respect for human rights in the EU. ${ }^{282}$

The relationship underlying the European human rights architecture might be reminiscent of the features of federalist systems, where the ECHR stands as the ultimate guardian of human rights.

By embarking on the journey to analyze the issue of the relationship between a fair trial and refusing a submission to initiate a preliminary ruling procedure one cannot ignore the elephant in the room, namely the formally unregulated relationship between the EU legal order and the ECHR itself. In such context, defining the relationship between the preliminary ruling procedure and the right to a fair trial might serve as a topic which begins a wider debate.

${ }^{282}$ Majić H. \&Mintas Hodak Lj., op.cit. 


\section{LIST OF REFERENCES}

Books and monographs

Blutman L. 2014 Az Európai Uniójoga a gyakorlatban Budapest, HVG ORAC

Broberg P. \&Fenger N. Preliminary References as a Right: But for Whom? The Extent to which Preliminary Reference Decisions can be Subject to Appeal European Law Review 36(2)

Doobay, A. 2013 The right to a fair trial in light of the recent ECtHR and CJEU case-law ERA Forum 14

Gerards J. 2014 Advisory Opinions, Preliminary rulings and the New Protocol No. 16 to the European Convention of Human Rights: A Comparative and Critical Appraisal Maastricht Journal of European and Comparative law

Lacchi, C. 2015. The ECrtHR's Interference in the Dialogue between National Courts and the Court of Justice of the EU: Implications for the Preliminary Reference Procedure Review of European Administrative Law

Majić H. \& Mintas Hodak Lj. 2019 Preliminary reference procedure and the scope of judicial review of the European Court of Human Rights EU and Member States - Legal and Economic issues

Schabas,W.A. 2015 The European Convention on Human Rights A Commentary Oxford: Oxford University Press

\section{Internet sources}

Charter of Fundamental Rights of the European Union2012/C 326/02

Consolidated version of the Treaty on the Functioning of the European Union OJ C 326

Convention for the Protection of Human Rights and Fundamental Freedoms CETS No. 05. https://www.coe.int/en/web/conventions/full-list/-/conventions/treaty/005

Fundamental Rights Report 2019, Fundamental Rights Agency, ISBN 978-92-9474-895-9

Galera Rodrigo S. 2015 The right to a fair trial in the European Union: lights and shadows Revista Investigacoes Constitucionais vol.2 no.2

Limante A. Refusal to refer for a preliminary ruling and a right to a fair trial: Strasbourg court's position KSLR EU Law Blog available at: https://blogs.kcl.ac.uk/ kslreuropeanlawblog/?p=1098\#.XtdeqmgzaUk

Mavronicola, N. 2012. What is an "absolute right"? Deciphering Absoluteness in the Context of Article 3 of the European Convention on Human Rights Human Rights Law Review, 12(4) 
Mohay Á. 2020 The Dorobantu case and the applicability of the ECHR in the EU legal order Pécs Journal of International and European Law

Spielmann D. Allowing the Right Margin: The European Court of Human Rights and The National Margin of Appreciation Doctrine: Waiver or Subsidiarity of European

Review? Cambridge Yearbook of European Legal Studies 14.

Case law

Adams and Benn v. United Kingdom, Application No.: 28979/95,30343/96

ECLI:CE:ECHR:1997:0113DEC002897995

Avotins v. Latvia, Application No.: 17502/07ECLI:CE:ECHR:2016:0523JUD001750207

Baydar v. The Netherlands, application no. 55385/14

ECLI:CE:ECHR:2018:0424JUD005538514

Baydar v. the Netherlands, Application No.:55385/14

ECLI:CE:ECHR:2018:0424JUD005538514

Bosphorus Hava Yolları Turizmve Ticaret Anonim Şirketi v. İreland, Application No.: 45036/98 ECLI:CE:ECHR:2005:0630JUD004503698

C-283/81 - CILFIT v MinisterodellaSanità

Coëme and Others v. Belgium, Application No.:32492/96, 32547/96, 32548/96, 33209/96, 33210/96 ECLI:CE:ECHR:2000:0622JUD003249296

Dhahbiv. Italy, Application No.: 17120/09 ECLI:CE:ECHR:2014:0408JUD001712009 para.33.

Dotta v. Italy, Application No.: 38399/97, ECLI:CE:ECHR:1999:0907DEC003839997

Dumitru Tudor Dorobantu. Case C-128/18. ECLI:EU:C:2019:857

Harisch v. Germany, Application No.:50053/16

ECLI:CE:ECHR:2019:0411JUD005005316

Herma v. Germany, Application No.:

54193/07ECLI:CE:ECHR:2009:1208DEC005419307

Klass and Others V. Germany Application No.:5029/71

ECLI:CE:ECHR:1978:0906JUD000502971

Lutz John v. Germany Application No.:

15073/03ECLI:CE:ECHR:2007:0213DEC001507303

OPINION OF ADVOCATE GENERAL WAHL delivered on 13 May 2015 Joined Cases

C72/14 and C197/14 ECLI:EU:C:2015:319

Otto Preminger Institut v. Austria, Application 
No.:13470/87ECLI:CE:ECHR:1994:0920JUD001347087

Peter Moosbrugger v. Austria, Application No. 44861/98,

ECLI:CE:ECHR:1990:0305DEC001198186

RepcevirágSzövetkezet v. Hungary, Application No.:70750/14

ECLI:CE:ECHR:2019:0430JUD007075014

Roche v. United Kingdom, Application no. 32555/96

ECLI:CE:ECHR:2005:1019JUD003255596

Stichting Mothers of Srebrenica and others v. the Netherlands, Application

No.:65542/12ECLI:CE:ECHR:2013:0611DEC006554212

Taxquet v. Belgium, application no. 926/05, ECLI:CE:ECHR:2010:1116JUD000092605 